\title{
An Assessment of Employee Perceptions on Team Based Practices in Adoption of Hydrogen Fuel Cell Vehicles (HFCV): A Study at Johor Bahru Industrial Area, Johor State of Malaysia
}

\author{
RUSINAH SIRON \\ Graduate Business School, College of Graduate Studies, Universiti Tenaga Nasional \\ Email: Rusinah@uniten.edu.my
}

TAN KWE LU

Institute of Energy Policy and Research, Universiti Tenaga Nasional Email: Tan@uniten.edu.my

MOHD AMIN TASRIPAN

College of Foundation and General Studies, Universiti Tenaga Nasional

Email: Amin@uniten.edu.my

\section{SITTI NURSAADAH MD RUSLI}

College of Graduate Studies, Universiti Tenaga Nasional Email: sitti1990@yahoo.com

\begin{abstract}
This paper presents the results of a study on the assessment of team based practices in the adoption of hydrogen fuel cell vehicles (HFCV) at Johor Bahru, Malaysia as the focus study area. The results show that the average total score of respondents' agreement on team based development items is at 30.3\% while the team based management items average agreement is at 32.7\%. The team based processes items scored $26.7 \%$ and the team based leadership average acceptance is at $31 \%$. On overall, the study indicates a good signal that the adoption of HFCV will be accepted if the team based practices can be improved for better direction of HFCV in Johor Bahru industrial area, Johor State Malaysia specifically.
\end{abstract}

Keywords: Team Based Practices, Hydrogen Fuel Cell Vehicle, Team Based Development, Team Based Management, Team Based Processes, Team Based Leadership.

\section{Introduction}

Hydrogen is particularly useful as an energy carrier, because it allows low-carbon energy to be stored. Small quantities of hydrogen with low-carbon foot-print can be stored under restricted space and weight requirements to enable long distance, low-carbon driving using fuel cell electric vehicles (FCEVs). FCEVs are essentially electric vehicles using hydrogen stored in a pressurized tank and a fuel cell for on board power generation. Today, around 550 FCEVs (passenger cars and buses) are running in several demonstration projects across the world (Table 1). Europe showed the highest demonstration FCEVs projects with 192 unit, United States 146 unit, Japan 100 unit and Korea, 100 unit (as per reference by Technology Roadmap, Hydrogen and Fuel Cells - International Energy Agency, 2015). The success story 
of hydrogen fuel cell vehicles adoption at some part of the countries lead to one of the successful formula is the team-based practices. In order to attain greater adoption of HFCV in the move towards sustainable business operations, organizations must make more use of their staff, adapting participatory management structures and processes to unlock new ideas, innovation and creativity through team based practices efficiently.

\section{Literature Review}

The development of HFCV very much depends on the development of the teamwork in the organization as teams must look for new ways to adapt quickly, operate more efficiently and better prepare for the fast and furious development of vehicles industries. Many organizations in the automotive industry believe in redesigning the team structure to meet the demand of work and pressure. The model of team based practices that is believed to affect the organization effectiveness is shown in Figure 1.

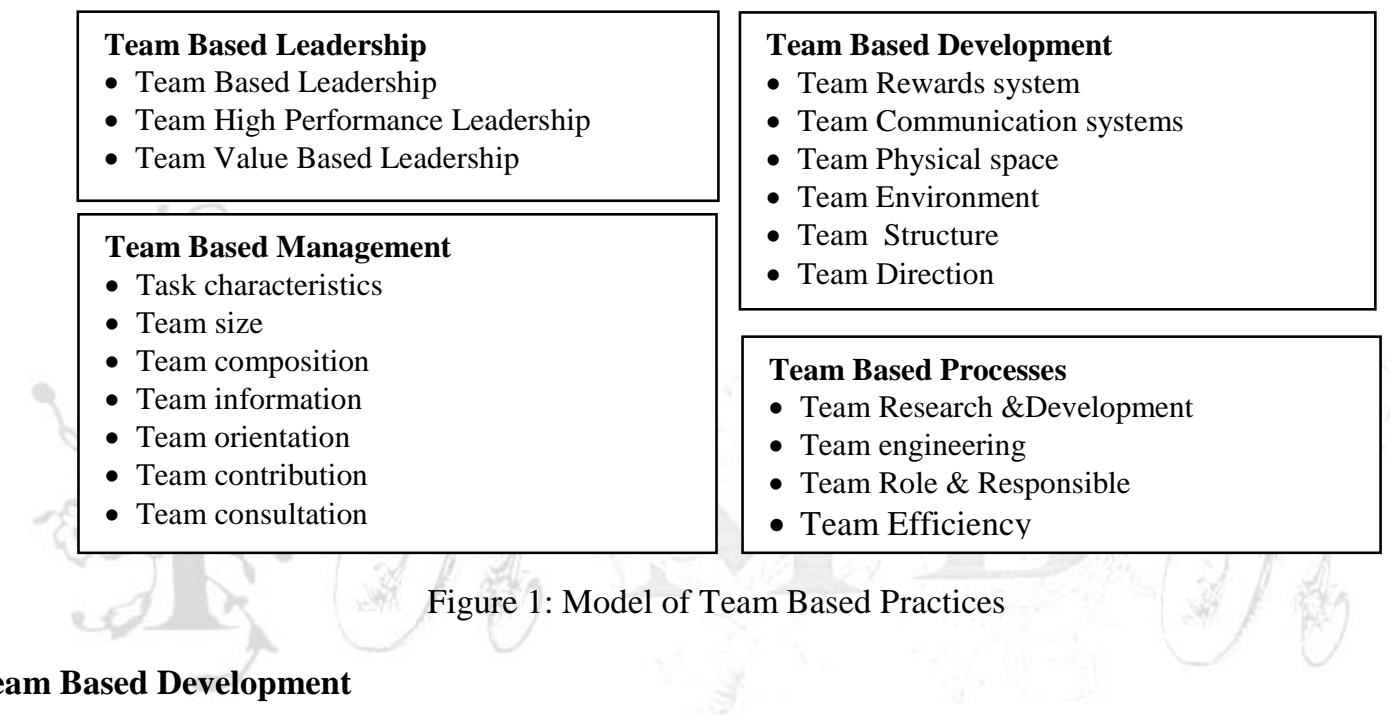

The team based development consists of the following:

- Team rewards systems include the reward strategies that can affect the huge increase in organization moving to team-based environment

- Team communication systems consists of communication media that is used within the team.

- Team physical space is required for the team to move around effectively like the layout, design and infrastructure.

- Team environment provides an internal environment such as motivation from staff and an external environment like stakeholders.

(Source: Elnaga and Imran (2013); Rochon (2014) and Zincirkiran et al. (2015) and adapted to suit the study requirements)

\section{Team Based Processes}

Team based processes consists of the following:

- Team research and development reflect on the research based in many forms like speed, accuracy, services and the training and development 
- Team engineering states how the team use skills and knowledge in engineering based competency

- Team role and responsibility reflects on the team members role and responsibility in handling their job

- Team efficiency focusses on members' expertise, education and ethics.

(Source: Ghorbanhosseini (2012); Jalal Hanaysha (2016) and adapted to suit the study requirements).

\section{Team Based Management}

Team based management suggest how the team should be managed efficiently:

- Team characteristics should be focused on the team structures like matrix structures or departmentalization structures or any structures that can adopt and adapt to HFCV.

- Team size should be determined on the number of team members.

- Team information stresses on how team will get information and disseminate the information.

- Team orientation focuses on the how the team members reinforce of behaviors to be in team.

- Team contribution stresses on the each team members can play their role in the team.

- Team consultation focuses on the ability of team members to give the consultation to members, clients, customers and community.

(Source: Hamid Tohidi (2011); Montgomery et al (2015) and adapted to suit the study requirements)

\section{Team Based Leadership}

The team based leadership affects team leaders' performance and style of leadership and consists of the following:

- Team based leadership consists of the style of leadership and their competencies.

- Team high performance leadership reflect on the ability of the leader to bring the performance of the members to the highest level.

- Team value based leadership can be illustrated as the leader setting the values of competency and caring for the group.

(Source: Shim et al (2004); Lock and Crawford (2004) and adapted to suit the study requirements).

\section{Research Methodology}

\section{Research Objective}

The objective of the study is to assess the team based practices towards the adoption of the HFCV with focus on Johor Bahru Industrial Area at Johor state, Malaysia.

\section{Research Instrument}

The team-based practices consist of four dimensions which is Team Based Development with eight item statements, the Team Based Management dimensions with 10 item statements, the Team Based Processes dimension with eight item statements and the Team Based Leadership with 18 item statements.

The questionnaire is measured using a 5-point Likert-scale ranging from (1) Strongly Disagree, (2) Disagree, (3) Moderately Agree, (4) Agree and (5) Strongly Agree. The researcher adapted and adjusted the questionnaire according to the requirements and need of team based practices with the adoption of HCFV as required. 


\section{The Respondents}

A pilot study was conducted among 25 respondents from various level of position in Bangi Industrial Area, Selangor, Malaysia. The result of Pilot Study is presented in Table 1:

Table 1: Reliability Analysis of Pilot Study

\begin{tabular}{|lcc|}
\hline Independent Variables & No of Items & $\begin{array}{c}\text { Cronbach } \\
\text { Alpha Value }\end{array}$ \\
\hline Team Based Practices: & & \\
. Team-Based Development & 10 & 0.67 \\
- Team-Based Management & 10 & 0.75 \\
- Team-Based Processes & 12 & 0.70 \\
Team Based Leadership & 18 & 0.74 \\
$\quad$ Total Items & $\mathbf{5 0}$ & \\
\hline
\end{tabular}

The 250 respondents of this study are specifically from the automotive industries around Johor Bahru, Johor State, Malaysia industrial area. They hold various positions from support staff to administrators and managers.

\section{Research Findings}

The findings of the research are presented as follows:

\section{Section A - Demographic Profile}

The majority demographic profile of the respondents from the Johor Bahru Industrial Area is summarized in Table 2.

Table 2: Summary of Demographic Profile of Respondent

\begin{tabular}{|lllc|}
\hline \hline No. & Demographic Variable & Majority & $\%$ \\
\hline 1. & Gender & Male & 64.2 \\
2. & Citizen & Citizen & 100.0 \\
$\mathbf{3 .}$ & Age & $21-30$ Years & 45.5 \\
$\mathbf{4 .}$ & Race & Malay & 86.5 \\
$\mathbf{5 .}$ & Religion & Muslim & 86.5 \\
$\mathbf{6 .}$ & Education Level & Diploma \& Degree & 71.5 \\
7. & Job Category & Operation & 41.8 \\
8. & Monthly Income & RM 1,001 - RM 5,000 & 51.2 \\
\hline \hline
\end{tabular}

The results as shown in Table 1 shows the majority of respondents who participated in this study found that there are $64.2 \%$ respondents were male and all the respondents are citizens of Malaysia (100\%). The survey respondents are composed primarily of between 21-30 years of age, accounting for $45.5 \%$ of the respondents. In terms of race, $86.5 \%$ of respondent are Malays and $71.5 \%$ majority respondents have their diploma and degree while $41.8 \%$ holds operational jobs. The $51.2 \%$ of the of the sample population have a monthly income from RM 1,001- RM 5,000 in Johor Bahru Industrial Area, Johor.

\section{Section B: Findings in Open Ended Questions}

The findings on open ended question are presented in Table 3. 


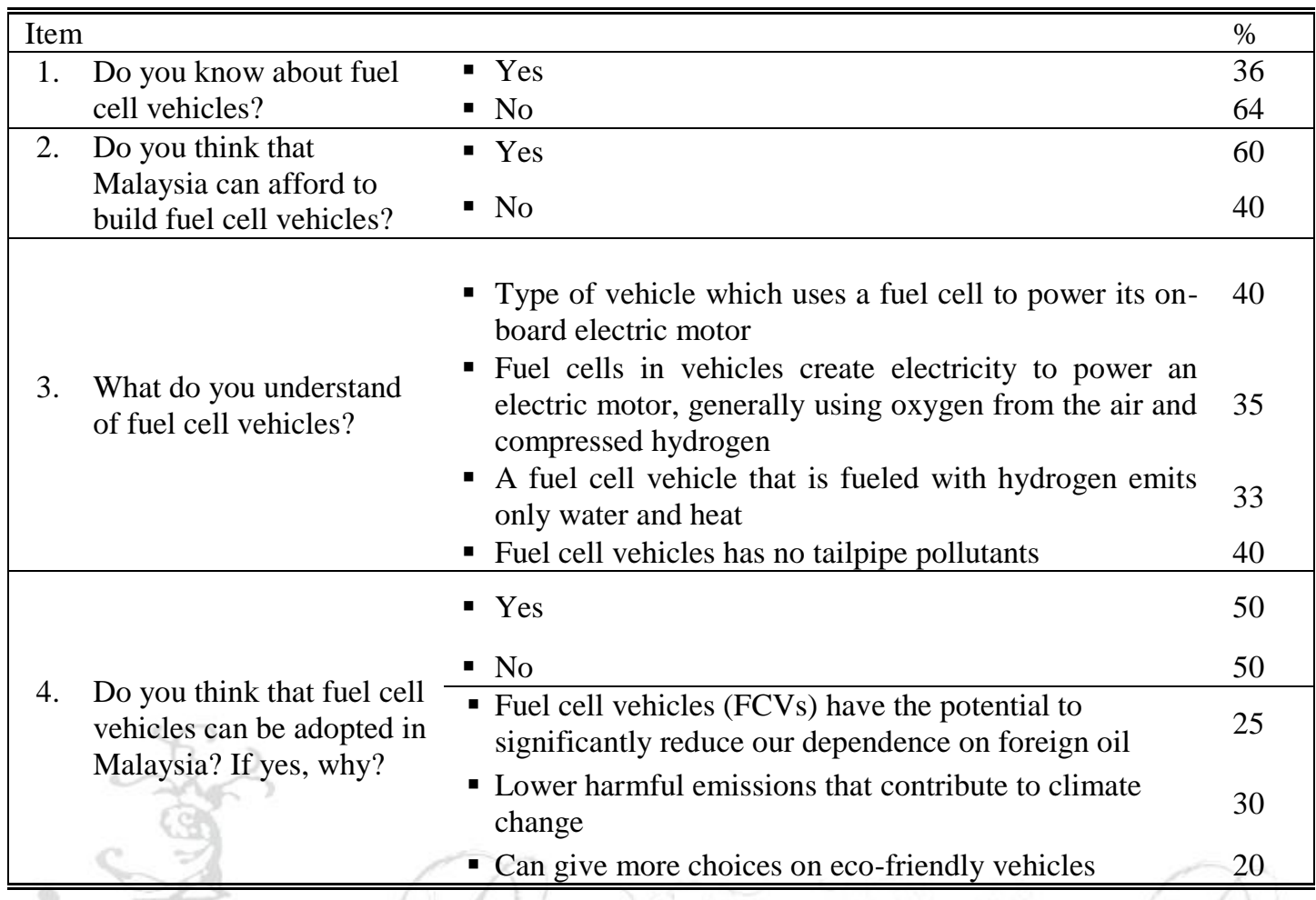

Presentations of the results of the study are presented with the percentage of agreement scale as follows:

Table 3: The Team Based Development

No. Statement Item

THE TEAM BASED DEVELOPMENT ITEMS

In my opinion, if HFCV is adopted in my organization, my perception on the following are as follows:

The HFCV team will:

1. Have the freedom to adapt their goals as needed in adoption of HFCV

2. Treat members as equals, regardless of rank, culture, or other differences for management

2. successfulness in adoption of HFCV

3. Focus both on the group's task and on how well the group is working in HFCV management

4. Revise their thinking as a result of group discussions or information collected in HFCV

4. operation 47

5. Reward for their achievements as a team in HFCV management initiatives.

6. Be confident that the organization will act on their recommendations in HFCV operation management

7. Communicated mostly directly and personally with each other's related with HFCV

7. management

8. Manage project-relevant information was shared openly by all team members.

9. Feel competent to perform the HFCV tasks required

10. Trust their team members to make appropriate decisions in job 
Table 4: The Team Based Management

\begin{tabular}{|c|c|c|}
\hline No. & Statement Item & $\%$ \\
\hline & THE TEAM BASED MANAGEMENT ITEMS & \\
\hline & In my opinions, if HFCV is adopted in my organization, my perceptions on the & \\
\hline & following were as follows: & \\
\hline & The HFCV management team will: & \\
\hline 1. & Be happy with the usefulness of the information received from other team members on & \\
\hline 1. & HFCV & 37 \\
\hline 2. & $\begin{array}{l}\text { Recognized the specific potentials (strengths and weaknesses) of individual team } \\
\text { members. }\end{array}$ & 25 \\
\hline 3. & $\begin{array}{l}\text { Contributing to the achievement of the team's goals in accordance to their specific } \\
\text { potentials. }\end{array}$ & 32 \\
\hline 4. & $\begin{array}{l}\text { Helped and supported each other as best as they can could in green environment } \\
\text { initiatives }\end{array}$ & 25 \\
\hline 5. & $\begin{array}{l}\text { Do suggestions and contributions of HFCV team members were discussed and further } \\
\text { developed and evaluated }\end{array}$ & 29 \\
\hline 6. & $\begin{array}{l}\text { Be acknowledged conflict and worked to resolve issues on the team related with HFCV } \\
\text { operation and management }\end{array}$ & 32 \\
\hline 7. & $\begin{array}{l}\text { Helped other team by sharing knowledge and information in HFCV operation and the } \\
\text { administration }\end{array}$ & 38 \\
\hline 8. & Be freely share HFCV information (technical, market, etc.) with others on the team. & 43 \\
\hline 9. & $\begin{array}{l}\text { Demonstrated interest and enthusiasm during green management team activities and } \\
\text { the HFCV program }\end{array}$ & 28 \\
\hline 10. & Acknowledged the contributions made by members on the team & 38 \\
\hline & AVERAGE TOTAL SCORE & 32.7 \\
\hline
\end{tabular}

Table 5: The Team Based Processes

\begin{tabular}{|c|c|c|}
\hline No. & Statement Item & $\%$ \\
\hline \multirow{2}{*}{\multicolumn{3}{|c|}{$\begin{array}{l}\text { THE TEAM BASED PROCESSES ITEMS } \\
\text { In my opinions, if HFCV is adopted in my organization, my perceptions on the }\end{array}$}} \\
\hline & & \\
\hline \multicolumn{3}{|c|}{ following were as follows: } \\
\hline & \multicolumn{2}{|l|}{ The HFCV teams will: } \\
\hline 1 & 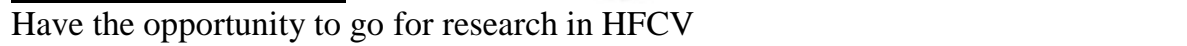 & 42 \\
\hline 2 & Get support from management to develop the program in learning and training & 34 \\
\hline & Be focus both on the group's task and on how well the group is working in HFCV & \\
\hline 3 & management and operation & 29 \\
\hline & \multicolumn{2}{|l|}{ Has an initiatives to strengthen the engineering processes operation and development } \\
\hline 4 & of HFCV & 23 \\
\hline 5 & \multicolumn{2}{|l|}{ Be train and well equip with the efficiency procedures and achievement of HFCV } \\
\hline & \multicolumn{2}{|l|}{ Be well supervise and train on their role and responsibility of HFCV processes and } \\
\hline 6 & HFCV operation & 28 \\
\hline 7 & \multirow{2}{*}{$\begin{array}{l}\text { Be efficient and effective to deal with HFCV operations and construction } \\
\text { Have good relationship with management when come to conflict or problems in }\end{array}$} & 24 \\
\hline & & \\
\hline 8 & HFCV operation & 25 \\
\hline 9 & Be encouraged and rewarded in HFCV training and development & 20 \\
\hline 10 & Receive applicable training to my HFCV job & 26 \\
\hline 11 & Receive in training and development that meets HFCV needs & 21 \\
\hline 12 & Be satisfied with the amount of training receive on the HFCV job & 18 \\
\hline & AVERAGE TOTAL SCORE & 24.2 \\
\hline
\end{tabular}


Table 6: The Team Based Leadership

\begin{tabular}{|c|c|c|}
\hline \multirow[t]{4}{*}{ No. } & Statement Item & $\%$ \\
\hline & THE TEAM BASED LEADERSHIP ITEMS & \\
\hline & In my opinions, if HFCV is adopted in my organization, my perceptions on the & \\
\hline & following were as follows: & \\
\hline & The HFCV teams will: & \\
\hline 1. & Have the ability to create group synergy. & 22 \\
\hline 2. & Have the ability to build team bonds. & 39 \\
\hline 3. & Have the ability to express team working encouragement. & 31 \\
\hline 5. & Have the ability to provide task motivation. & 35 \\
\hline 6. & Have the ability to be persuasive in work. & 31 \\
\hline 7. & Have the ability to be a change catalyst in working environment. & 25 \\
\hline 8. & Have the way to helps employees to make working on their tasks more pleasant. & 37 \\
\hline 9. & Have the way to treats team members as equals. & 29 \\
\hline 10. & Have the ability to explain the way how the tasks should be carried out. & 27 \\
\hline 11. & Have the ability to decide what and how things shall be done in management. & 32 \\
\hline 12. & Have to focus to maintain definite standards of work performance. & 45 \\
\hline 13. & Have the way to schedules the planning of the work implementation. & 32 \\
\hline 14. & Have the skill to demonstrate good communication skills. & 26 \\
\hline 15. & Have the potential to demonstrate positive leadership qualities in HFCV management. & 35 \\
\hline 16. & Have the ability to develop practical and realistic programs in HFCV management & 30 \\
\hline 17. & $\begin{array}{l}\text { Have the ability to analyze problems in green management and arrive at appropriate } \\
\text { solutions. }\end{array}$ & 42 \\
\hline 18. & $\begin{array}{l}\text { Have to be enthusiastic and motivated in performing duties in HFCV management. } \\
\text { AVERAGE TOTAL SCORE }\end{array}$ & $\begin{array}{l}44 \\
31.0\end{array}$ \\
\hline
\end{tabular}

\section{Conclusion}

The result shows that the respondents involved agree with the constructive element of every dimension in the questionnaire. Based on the results, in general, the employee perception level in the Team-Based Practices are at the level 'agreed' on overall the four dimension of team based practices are $31 \%$. Several suggestions have been listed to help strengthen Team-Based Practices in adoption of Hydrogen Fuel Cell Vehicles in Malaysia. Some of the suggestions are as follows:

\section{Team Based Development:}

- Give freedom to team on endorsement and trust i organization sustainability initiatives.

- Help problem solving team to make maximum use of members' resources and contributions.

- Help members to develop a high level of motivation to carry out team decisions.

- Help team to overcome specific problem in HFCV like complaints, confusion about tasks and conflicts.

- Involving members with common organizational goals.

- Seek talent within team members.

- Develop team member skills.

- Team expertise need to expose positively.

- Team confidence in jobs.

- Team satisfaction must be increased.

- Team relationship must be bonded positively. 


\section{Team Based Management:}

- $\quad$ Provide directions for the organizations performance.

- Establishing indicators to determine HFCV performance.

- Communicating the HFCV policy and goals, the processes required to achieve HFCV progress.

- Focused on organization HFCV issues related.

- Monitoring HFCV quality.

- Consultation and confrontation meetings progressively.

- Improve levels of communication, training and feedback.

- Promote the use of teamwork across functional boundaries.

- Team remunerations.

- Safety and security of team at the workplace.

- Organizational policies and management style.

- Organizational support.

\section{Team Based Processes:}

- Management Support needs to be open and always ready for its employees who need guidance in adoption of HFCV.

- Group Synergy to identify the strength and weakness of the team and evaluate employee to expose interpersonal skill.

- Team Activity together with the team members for example, a round table discussion to strengthen the bond of the team in creating a productive HFCV work quality.

- Job Involvement: Creating a forum for employee on the development and sharing of ideas in increasing the performance of the HFCV operation, this can be an effective of job involvement among employees in the HFCV operation.

- Integrate safety and sustainably strategies for HFCV responsibility and accountability.

- Build capabilities on tools and materials.

- Assessment on teams.

- Integrate health and safety of team members.

Team Based Leadership:

- Leadership Behavior: HFCV leader has to create a sense of trust and mutual understanding between a leader and team members.

- Leaders developing accountability and extraordinary performance in building trust is important by a strong foundation of good relationship between a leader and team members.

- Motivation: HFCV leader that is geared towards HFCV high performance, HFCV leader has to obtain the correct motivation. This is because a team depends on its leader to direct where and how to execute the delegated task.

- Long-term Development: The organization needs to review all the HFCV training that has been done in order for the training value of the employee is parallel to the organization and the current condition as well as encouraging the involvement and commitment of employee in the long run.

- Comprehensive Program: Every employee in an adoption of HFCV has to be equipped with specialized skill, depending on their job specification and role in the organization. The leaders needs to decide training goal that is specific and realistic in HFCV operation.

- Improve Performance: The HFCV training program should be suitable with the employee's needs and applied by the knowledge that has been gained to their delegated task, it is deemed constructive in enhancing employee work performance.

- Employees Evaluation: Consistent feedback from high performance leaders in HFCV enables employees to know that every action done by them affects the organization. The organization 
needs to be specific in giving feedbacks of HFCV performance. The HFCV working team should be free to decide on how to carry out their work properly and treat team members equally without making any distinction among each other for the successful of HFCV Team-Based Practices in organizations. The HFCV working team should be more focus on the tasks given and make regularly review the results of the green group discussions or information that has been collected.

The HFCV working team need to increase their confidence in the suggestions that they has been proposed to the management and increase their mutual helped and supported each other's in the team to share knowledge and information. The HFCV management should give a reward for the every achievement of the team who have contributed to the achievement of the team.

\section{Acknowledgement}

We would like to express the deepest appreciation to Ministry of Education (MOE) Malaysia for funding this research under LRGS project of 'Zero Emission Fuel Cell Vehicle Powered by Hydrogen Energy: Economic, Social and Environmental Impact of Introduction of Fuel Cell Vehicles.' The authors would like to thank UNITEN, UKM and MOE Malaysia for the support upon completion of this research.

\section{References}

Cohen SG, Bailey DE. What makes teams work: Group effectiveness research from the shop floor to the executive suite. Journal of Management, 23:239-290. (1997)

Elnaga, A. and Imran, A. (2013). The Effect of Training on Employee Performance. European Journal of Business and Management, 5(4), 137-147.

Ghorbanhosseini, M. (2012). Analysis of team working on organizational commitment in Safa Industries Group in Iran. International Journal of Engineeering and Science, I (3), 22-25.

Hamid Tohidi (2011). Teamwork Productivity and Effectiveness in an Organization based on rewards, leadership, training, goals, wage, size, motivation, measurement and information technology. Elsevier at www.sciencedirect.com

Lok, P. and Crawford, J. (2004). The Effects of Organizational Culture and Leadership Style on Job Satisfaction and Organizational Commitment. Journal of Managament Development, Vol. 23. No 3/4 pp. 321-38.

Montgomery, A. Spanu, F., Baban, A., and Panagopoulu, E. (2015). Job demands, burnout, and engagement among nurses: A multi level analysis of ORCAB data investigating the moderating effect of teamwork. Burnout Research 2 (2015), 71-79.

Marks MA., Mathieu JF and Zaccaro, SJ. A temporally based framework and taxonomy of team processes. Academy Management Revew, (2001), 26:356-376

Shim, S. Lusch, R.F. and Goldsberry, E. (2002). Leadership style profiles or retail managers: Personal. Organizational, and managerial characteristics. International Journal of Retail \& Distribution Management, Vol. 30, No.4 pp.186-201.

Technology Roadmap: Hydrogen and Fuel Cells, International Energy Agency, 2015.

Weeda, M.et al. (2014), Towards a Comprehensive Hydrogen Insfrasturcture for Fuel Cell Electric Cars in view of EU GHG Reduction Targets, Hydrogen Infrastrucure for Transport (HIT)

Zincirkiran, M. Emhan, A., and Yasar, M. F. (2015). Analysis of teamwork, organizational commitment and organizational performance: A Study of Health Sector in Turkey. Asian Journal of Business and Management, 3(2), 173-182. 